\title{
Karakteristik Perkuatan Dinding Bata Merah dengan Menggunakan Tulangan Diagonal Eksternal
}

\author{
Akhmad Yusuf Zuhdy, Buyung Anugraha \\ Staft Pengajar Program Studi D-III Teknik Sipil FTSP - ITS \\ email: yusuf_zuhdi@ce.its.ac.id; r_buyung_aa@ce.its.ac.id \\ Deni David \\ Dosen Jurusan Teknik Sipil Fak. Teknik Universitas Atmajaya Yogyakarta
}

\begin{abstract}
ABSTRAK
Perencanaan gempa pada suatu bangunan sering dilakukan hanya pada bagian struktural tapi melupakan adanya bagian non-struktural, seperti dinding. Untuk meminimalisasi kerusakan non-struktural akibat gempa maka perlu dilakukan penelitian dinding dengan bata merah sebagai pengisi yang umum banyak dipakai oleh masyararat dengan parameter meliputi: hubungan beban simpangan, pola retak, drift ratio, stiffness, maximum shear strength, shear modulus, damping dan daktilitas serta pengaruh penambahan tulangan diagonal diharapkan dapat teridentifikasi dari penelitian.

Untuk penelitian ini digunakan satu buah model struktur dengan ukuran dinding $3000 \mathrm{x}$ $3000 \times 100 \mathrm{~mm}$ yaitu dinding bata merah dengan penambahan tulangan diagonal (Infilled Frame With Diagonal Bar, IFWDB). Metode pembebanan dilakukan dengan menggunakan beban horisontal bolak-balik untuk memodelkan beban gempa yang mengacu pada standar ASTM E2126-02a.

Berdasarkan hasil penelitian, penambahan tulangan diagonal pada pasangan dinding bata merah dapat meningkatkan kemampuan struktur dalam menerima beban sebesar $119,190 \%$ meningkatkan simpangan failure sebesar $148,309 \%$, meningkatkan kuat geser ultimit sebesar $119,184 \%$, meningkatkan besarnya energi hysteretic dan energi potensial struktur pada setiap siklus, dan dapat digunakan pada semua wilayah gempa. Kerusakan yang terbentuk lebih banyak merupakan jenis kerusakan geser.
\end{abstract}

Kata kunci : dinding bata merah, tulangan diagonal, pembebanan horisontal bolakbalik.

\section{PENDAHULUAN}

\section{A. Latar Belakang}

Dinding merupakan bagian bangunan yang getas dan paling rentan terhadap goncangan gaya horisontal, oleh karenanya sangat penting untuk memperbaiki kinerja dinding agar lebih tahan terhadap gaya horisontal. Getaran tanah saat terjadi gempa menyebabkan gaya inersia pada massa bangunan yang merambat dari pondasi dan dinding hingga ke atap. Yang harus ditekankan adalah menjamin agar gaya tersebut mencapai atap tanpa menyebabkan kerusakan berat atau robohnya dinding. Dari tiga komponen rumah (atap, dinding, dan pondasi), dinding merupakan bagian yang paling rawan terhadap gaya horisontal gempa. Dinding akan jauh lebih kuat bila didorong ke arah memanjang dinding (disebut arah kuat/strong direction), tetapi akan mudah sekali roboh kalau bagian atasnya didorong ke samping sebidang pada arah tegak lurus bidang dinding (disebut arah lemah/weak direction).

Beberapa cara bisa dilakukan untuk menjadikan dinding lebih tahan terhadap gaya gempa, baik dinding tersebut berupa pembuatan dinding baru maupun berupa perbaikan dinding yang telah mengalami kerusakan akibat gaya horisontal. Berdasarkan FEMA 273, beberapa metode yang dapat dilakukan untuk perkuatan (strengthening) atau perbaikan (retrofitting) pada dinding antara lain membuat batasan pada bukaan dinding yang tidak lebih dari $40 \%$, melakukan perkuatan atau perbaikan dengan ferrocement, pemberian tulangan pada retakan, 
pemberian bahan grouting dengan cara injeksi yang dilakukan pada retak-retak yang terjadi, pelapisan dinding dengan mortar kuat lekat tinggi, pemasangan bracing berupa tulangan diagonal eksternal, dan penambahan elemen struktur eksternal yang berfungsi untuk menambah kekakuan dinding.

Penelitian dinding bata merah dengan perkuatan tulangan horisontal sudah pernah dilakukan oleh peneliti sebelumnya (Raharjo, 2005). Berdasarkan hal tersebut maka dilakukan penelitian lanjutan mengenai dinding bata merah tetapi dengan perkuatan tulangan diagonal/bracing eksternal. Penelitian ini membahas perilaku dinding bata merah dengan perkuatan tulangan diagonal/bracing eksternal akibat beban horisontal bolak-balik terhadap sumbu kuat dinding.

\section{B. Tujuan Penelitian}

Penelitian mengenai perbaikan dinding bata merah dengan menggunakan tulangan diagonal eksternal akibat beban horisontal bolak balik ini bertujuan untuk :

1. Mengetahui perilaku dinding bata merah dengan perkuatan tulangan diagonal/bracing eksternal yang meliputi hubungan beban-simpangan, kekakuan, redaman, kuat geser ultimit, daktilitas, dan pola retak dinding.

2. Mengetahui pengaruh penambahan tulangan diagonal/bracing eksternal pada dinding bata merah.

Membandingkan perilaku dinding bata merah dengan perkuatan tulangan diagonal/bracing eksternal terhadap dinding bata merah tanpa perkuatan tulangan horisontal (Infilled Frame Non Horizontal Bar/IFNHB) dan dengan perkuatan tulangan horisontal 6200 (Infilled Frame With Horizontal Bar/IFWHB) hasil penelitian eksperimental dari penelitian sebelumnya (Raharjo, 2005).

\section{Manfaat Penelitian}

Manfaat dari penelitian ini adalah untuk memberikan informasi dampak dari perbaikan dinding dalam mendukung kestabilan struktur dalam memikul beban bolak balik (siklik).

Selain itu, juga untuk memberikan masukan dalam menentukan salah satu metode perbaikan pada dinding dengan penambahan tulangan diagonal eksternal yang dipasang menyilang pada kedua sisi dinding.

\section{TINJAUAN PUSTAKA}

\section{A. Dinding Bata}

Dinding bata/batako merupakan bahan yang getas sehingga tidak mampu menahan gaya tarik dan lentur, sedangkan kemampuan dinding bata/batako menahan gaya tekan sangat dipengaruhi oleh mutu bahan, mutu campuran adukan, dan mutu pelaksanaan dinding itu sendiri (Tular, 1981).

Dinding pasangan bata mempunyai kekuatan tarik terpasang sekitar 1,5-2,0\% dari kekuatan tekannya sehingga mudah retak/hancur akibat beban lateral yang menghasilkan tarikan/puntiran/geser pada dinding pasangan tersebut. Dinding pasangan yang diperkuat dengan frame (kolom+balok) dari beton bertulang, lebih kuat untuk menahan gaya lateral segala arah akibat beban gempa, karena dapat berfungsi sebagai confined masonry sehingga memiliki kemampuan sebagai dinding geser dengan kekuatan terbatas selama dinding tersebut masih berdiri pada posisinya dan memiliki ikatan dengan frame tersebut, misalnya dengan batang baja jangkar (Siddiq, 2000).

\section{A. Penelitian Dinding Bata}

Penelitian eksperimental Raharjo (2005) terhadap 3 model rangka terbuka (Open Frame, Infilled Frame Non Horisontal Bars, Infilled Frame With Horisontal Bars dengan pembebanan horisontal bolak-balik mempunyai kesimpulan sebagai berikut :

1. Meningkatkan kemampuan struktur dalam menerima beban dengan parameter pengamatan beban crack, yield, ultimate, dan failure. Untuk initial condition berturut-turut mengalami peningkatan sebesar $160,522 \%$; $20,484 \%$; $15,641 \%$; $22.323 \%$, dan pada stabilized condition berturutturut mengalami peningkatan sebesar sebesar 160,522\%; 25,944\%; 30,227\%; 44,639\%.

2. Meningkatkan simpangan struktur pada parameter pengamatan saat crack, yield, ultimate, dan failure. Untuk initial condition berturut-turut 
mengalami peningkatan sebesar $170,588 \%$; 23,994\%; 98,038\%; 318,808\%, dan pada stabilized condition berturutturut mengalami peningkatan sebesar sebesar $170,588 \%$; $11,128 \%$; 262,371\%; $364,110 \%$.

3. Meningkatkan kekakuan elastik equivalent benda uji IFWHB untuk initial condition sebesar $11,876 \%$ dan pada stabilized condition sebesar $18,815 \%$.

4. Peningkatan daktilitas struktur sebesar $225,221 \%$ pada initial condition dan $262,202 \%$ pada stabilized condition.

5. Meningkatkan maximum shear strength sebesar 15,636\% pada initial condition dan 30,228\% pada stabilized condition.

6. Meningkatkan besarnya energi hysteretic dan energi potensial struktur pada setiap siklus pada initial maupun stabilized condition.

Adanya tulangan horisontal menyebabkan struktur dinding menjadi lebih mampu menahan beban lateral yang besar, kerusakan awal struktur dapat dicegah dan pemisahan antara dinding dan rangka beton bertulang dapat diminimalisasikan (Raharjo, 2005).

Penelitian eksperimental Siddiq (2000) terhadap struktur dinding pasangan blok beton berongga bertulang akibat beban kombinasi aksial tekan dan beban lateral siklik (berupa beban geser sejajar bidang dinding), dan juga meneliti efektifitas baja tulangan penahan geser serta ragam keruntuhan (failure mode). Benda uji yang digunakan menggunakan hollow conblock HB-200 (tebal 200 mm), mutu HB-200 kuat tekan $f_{m}^{\prime}=3,20 \mathrm{MPa}$, tinggi dinding 2675 $\mathrm{mm}$, lebar denah $2670 \mathrm{~mm}$, diameter tulangan horisontal $8 \mathrm{~mm}$ dan diameter tulangan vertikal $12 \mathrm{~mm}$ serta mutu baja tulangan $f_{y}=390 \mathrm{MPa}$ dan menggunakan hollow conblock HB-150 (tebal $150 \mathrm{~mm}$ ), mutu HB-150 kuat tekan $f_{m}{ }^{\prime}=3,20 \mathrm{MPa}$, tinggi $\mathrm{H}_{1}=\mathrm{H}_{2}$ adalah $2440 \mathrm{~mm}$, panjang $2660 \mathrm{~mm}$, diameter tulangan horisontal 8 $\mathrm{mm}$ dan diameter tulangan vertikal $10 \mathrm{~mm}$ dan $12 \mathrm{~mm}$ serta mutu baja tulangan $f_{y}=$ $390 \mathrm{MPa}$.

Dari penelitian struktur pasangan blok beton berongga bertulang terhadap beban lateral siklis diatas dapat disimpulkan sebagaimana berikut :
1. Dinding pasangan tanpa tulangan, hanya kuat terhadap tekan, tetapi lemah terhadap tarik, geser dan torsi.

2. Bila diberi perkuatan tulangan baja penahan tarik (arah vertikal) dan tulangan penahan geser (arah horisontal), maka dinding pasangan dapat bersifat kuat terhadap lentur dan geser serta bersifat daktail terhadap beban lateral siklis.

3. Mutu bahan yang memadai dan metode kontruksi yang benar serta jumlah tulangan yang cukup/optimum membuat struktur dapat digunakan untuk 2 sampai 3 tingkat.

4. Struktur cukup daktail, dengan nilai daktilitas sebesar 5,09.

Siddiq (2000) menyatakan rusak atau robohnya struktur bangunan dinding pasangan dapat disebabkan oleh faktorfaktor berikut ini :

1. Mutu bahan pasangan, terutama mortar sangat rendah, dan bukaan pada dinding terlalu lebar.

2. Teknik pengerjaan dinding pasangan kurang tepat.

3. Mengkombinasikan komponen struktur rangka dengan bahan yang berbeda sifat/karakteristiknya, tanpa sistem ikatan yang kuat.

4. Hubungan antara dinding pasangan dan frame tidak dilengkapi batang besi jangkar, pasangan roboh akibat face loads (beban tegak-lurus bidang).

5. Mutu beton yang sangat rendah dan banyak keropos.

6. Baja tulangan pada ujung balok tidak terjangkar dengan baik pada kolom, demikian juga dengan tulangan ujung kolom dan pondasi, sehingga join kolombalok sangat mudah rusak dan diikuti terlepasnya ikatan balok dengan kolom.

Goto et. al. (2003) melakukan penelitian mengenai perilaku dari dinding batu bata terkekang akibat pengaruh beban aksial dan akibat perkuatan tulangan horisontal terhadap pembebanan horisontal. Kesimpulan yang diperoleh, yaitu bahwa perkuatan tulangan horisontal pada dinding terkekang mampu meningkatkan ketahanan dari dinding dan dapat menambah panjang simpangan horisontal. 
Penelitian Mangkoesoebroto, et. al. (2003) menggunakan dinding pasangan bata merah $(R B)$, batako berlubang $(C W)$, batako berlubang dengan penulangan horisontal (CWHR), dengan pembebanan bolak-balik. Kesimpulan yang diperoleh yaitu bahwa dinding dengan pasangan bata merah $(R B)$ mempunyai tahanan gaya lateral terbesar, yang kemudian diikuti oleh dinding pasangan batako $(C W)$, dan dinding pasangan batako dengan penulangan horisontal (CWHR). Rendahnya kekuatan dinding pasangan batako terhadap dinding pasangan bata merah disebabkan karena kuat tekan material batako lebih rendah dibandingkan dengan material bata merah, dan bentuk fisik material bata merah lebih padat sedangkan pada batako berlobang (hollow conblock), serta penggunaan mortar yang lebih banyak pada dinding pasangan bata merah. Lebih rendahnya kekuatan struktur CWHR dibandingkan struktur $C W$ karena terjadinya kerusakan pada pertemuan antara mortar dengan pasangan batako akibat adanya tulangan.

\section{METODE PENELITIAN}

\section{A. Tahapan Persiapan}

Benda uji dibuat seperti pada Gambar 1 yaitu dinding bata merah dengan perkuatan tulangan diagonal/bracing eksternal (Infilled Frame With Diagonal Bar /IFWDB) sebanyak 1 (satu) buah.

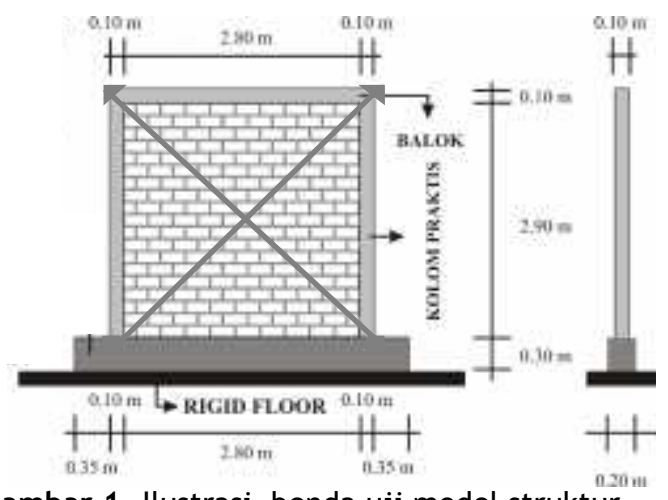

Gambar 1. Ilustrasi benda uji model struktur

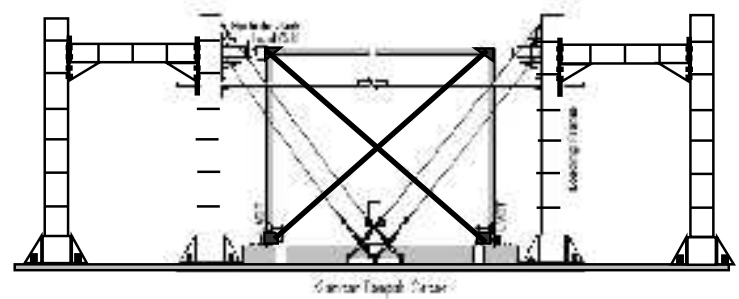

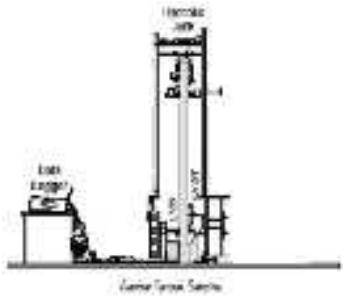

Gambar 2 Setting pengujian

\section{B. Tahapan Pengujian Model Struktur}

Pengujian dilakukan dengan cara memberikan beban horisontal pada struktur dengan menggunakan hidraulic jack pada arah sejajar sisi kuat dinding pasangan bata merah. Beban horisontal ini dimaksudkan untuk memodelkan beban gempa yang terjadi pada sumbu kuat dinding. Pembebanan dilakukan berdasarkan ASTM E2126-02a Metode B (Standar Test Methods for Cyclic (Reserved) Load Test for Shear Resistance of Walls for Buildings).

\section{HASIL DAN PEMBAHASAN}

A. Pengujian Model Struktur

Pengujian terhadap model benda uji dilakukan dengan memodelkan beban gempa yang terjadi sebagai beban lateral bolakbalik yang terjadi pada ujung atas struktur. Untuk pengujian ini diperlukan data simpangan runtuh $/ \Delta_{u}$ dari hasil pengujian statik yang dilakukan oleh Setyawati, (2005). Data tersebut kemudian dijadikan referensi untuk melakukan pembebanan bolak-balik sesuai dengan standar yang berlaku pada ASTM E2126-02a.

\section{B. Hysteretic Curve}

Pengujian dilakukan dengan pembebanan horisontal bolak-balik menghasilkan hysteretic curve yang menggambarkan besarnya energi yang terdisipasi pada setiap siklusnya. Gambar 3 sampai Gambar 5 merupakan bentuk dari hysteretic curve dari benda uji IFWDB, IFNHB dan IFWHB. 


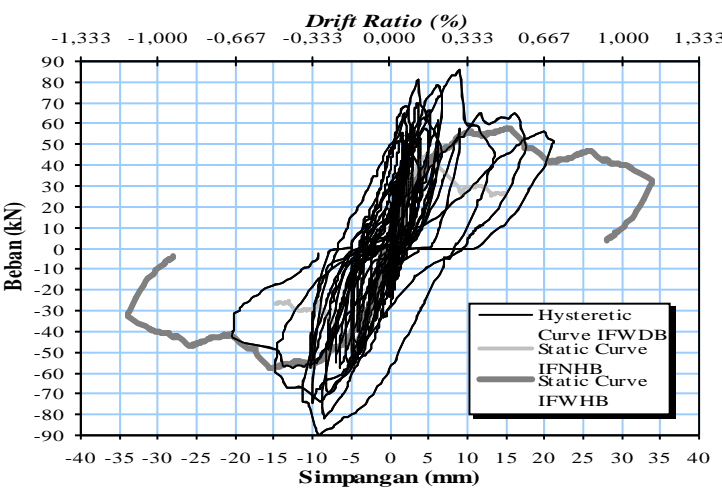

Gambar 3 Hysteretic curve benda uji IFWDB

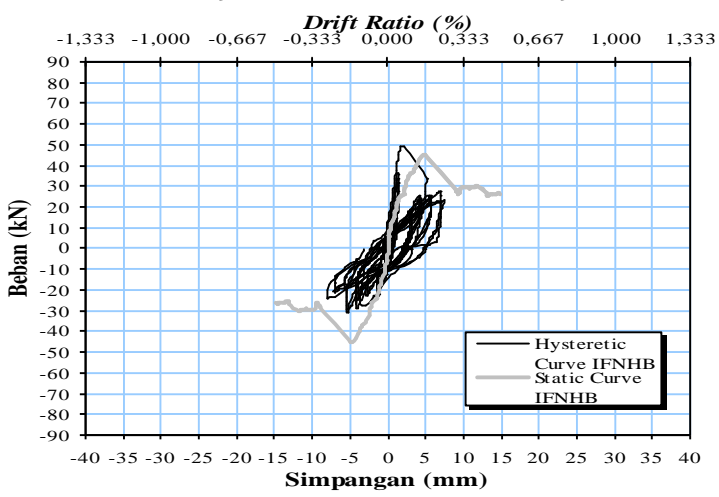

Gambar 4 Hysteretic curve benda uji IFNHB

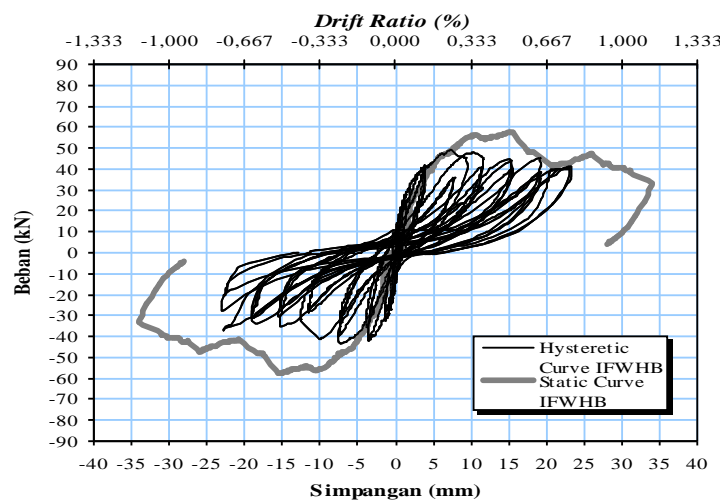

Gambar 5 Hysteretic curve benda uji IFWHB Berdasarkan hysteretic curve ketiga benda uji di atas terlihat bahwa IFWHB memiliki kemampuan berdeformasi yang paling besar, kemudian diikuti oleh benda uji IFWDB dan benda uji IFNHB. Walaupun memiliki kemampuan berdeformasi yang paling besar, namun IFWHB memiliki kapasitas tahanan gaya lateral yang lebih kecil dibandingkan dengan IFWDB. Secara grafis dapat dilihat bahwa hysteretic curve benda uji IFWDB mengikuti bentuk dari kurva bebansimpangan benda uji IFNHB dikarenakan pola pembebanan bolak-balik berdasarkan data simpangan runtuh $\left(\Delta_{u}\right)$ benda uji IFNHB dari pengujian statik Setyawati (2005).

Hysteretic curve ketiga benda uji di atas digambarkan dengan skala yang sama, dengan tujuan untuk menunjukkan benda uji IFWDB mampu menahan beban lateral yang lebih besar pada simpangan yang sama dengan benda uji IFNHB dan IFWHB.

\section{Envelope curve dan Equivalent Energy Elastic-Plastic Curve (EEEPC)}

Envelope curve merupakan pendekatan dari hysteretic curve yang didapatkan dari data beban puncak tiap siklus dan simpangan atau drift yang menyertainya baik pada kondisi initial maupun stabilized. Hasil pengujian dan analisis didapatkan bentuk envelope curve dapat dilihat pada Gambar 6.

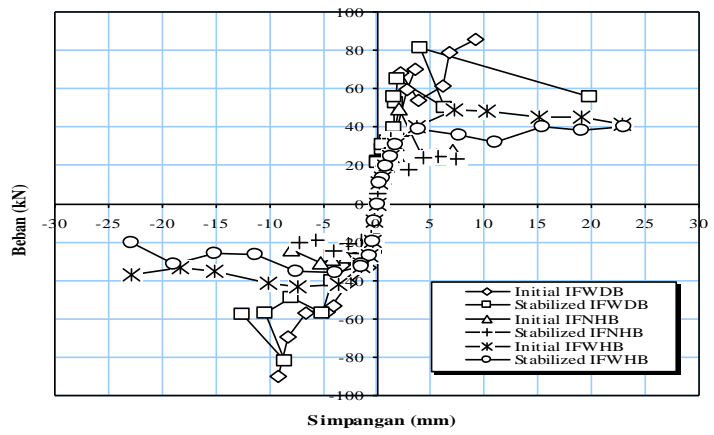

Gambar 6 Envelope curve benda uji IFWDB

Berdasarkan envelope curve yang telah dibentuk selanjutnya dilakukan analisis dengan membentuk equivalent energy elastic-plastic curve, Gambar 7 untuk mendapatkan parameter pengamatan berupa hubungan beban-simpangan pada saat crack, yield, ultimate dan failure. Analisis secara grafis di tampilkan pada Gambar 8 dan Gambar 9.

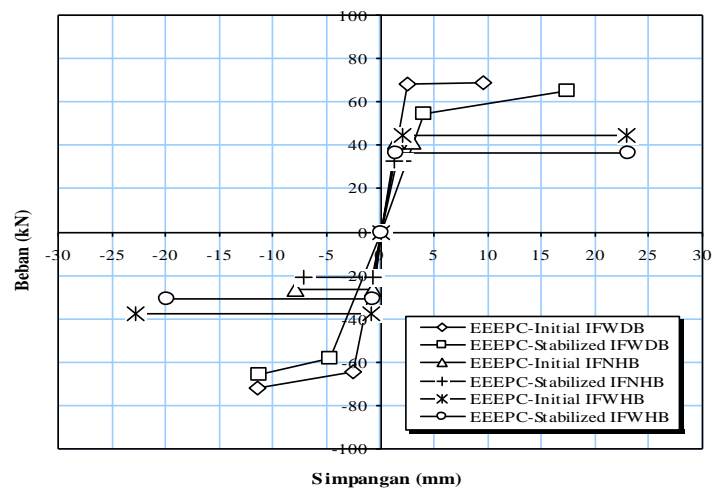

Gambar 7 EEEPC benda uji IFWDB 


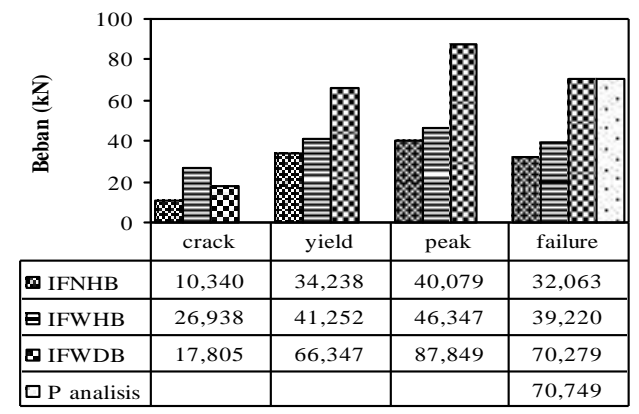

a. initial condition

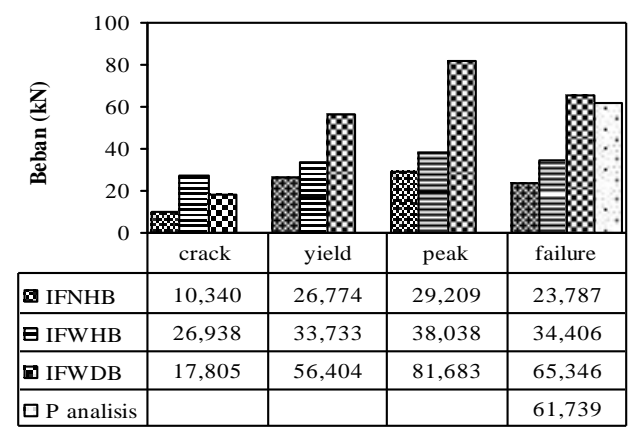

b. stabilized condition

Gambar 8 Beban lateral rata-rata

Gambar di atas menunjukkan bahwa benda uji IFWHB mempunyai tahanan gaya lateral terbesar hanya pada $P_{\text {crack }}$ yang kemudian diikuti benda uji IFWDB dan yang terakhir IFNHB, hal ini disebabkan karena perencanaan tulangan diagonal pada IFWDB baru bekerja setelah kondisi dinding mengalami crack. Untuk parameter pengamatan yang lain $\left(P_{\text {yield, }} P_{\text {peak }}\right.$, dan $\left.P_{\text {failure }}\right)$ IFWDB mempunyai tahanan gaya lateral yang lebih besar nilainya di atas benda uji IFWHB dan IFNHB. Oleh karena itu dalam hal ketahanan benda uji dalam menerima beban lateral, benda uji IFWDB paling baik, kemudian diikuti benda uji IFWHB dan yang terakhir IFNHB. Beban analisis merupakan beban perkiraan yang akan dicapai oleh benda uji IFWDB pada saat failure yang kemudian dibandingkan dengan beban failure yang terjadi sesungguhnya dari pengujian.

Untuk memperkirakan besarnya baban (P) secara analisis dapat dihitung sebagaimana berikut :

Diameter tulangan diagonal $=10 \mathrm{~mm}$, fy $=$ $341,682 \mathrm{MPa}$, As $=78,540 \mathrm{~mm}^{2} . \mathrm{P}_{n}=\mathrm{fy}$. As
$=26.835,64 \mathrm{~N}=2,684$ ton (per 1 tulangan diagonal) $\mathrm{P}_{u}=\mathrm{Pn}$. Cos $45=1.898$ ton (per 1 tulangan arah horizontal)

Ppeak IFNHB $=40.079 \mathrm{~N},=4.008$ Ton, Jumlah tulangan diagonal IFNHB $=2.112$ (dipakai 2 buah tulangan $\varnothing 10 \mathrm{~mm} / \mathrm{sisi}$ )

$\mathrm{P}_{\text {bracing }}$ IFWDB $=\mathrm{n} . \mathrm{Pu}=2 \times 1.898=37.951$ $\mathrm{kN}$

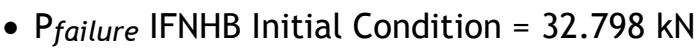

Pailure IFWDB $=32.798+37.951=70.749$ $\mathrm{kN}$

- P $_{\text {failure }}$ IFNHB Initial Condition = $23.787 \mathrm{kN}$

Pfailure IFWDB $=23.787+37.951=61.739$ $\mathrm{kN}$

Kenaikan $\mathrm{P}_{\text {failure }}$ IFWDB terhadap $\mathrm{P}_{\text {failure }}$ IFNHB merupakan kontribusi dari pemakaian tulangan diagonal. Hal ini ditunjukkan dengan nilai Panalisis yang mendekati Pfailure.

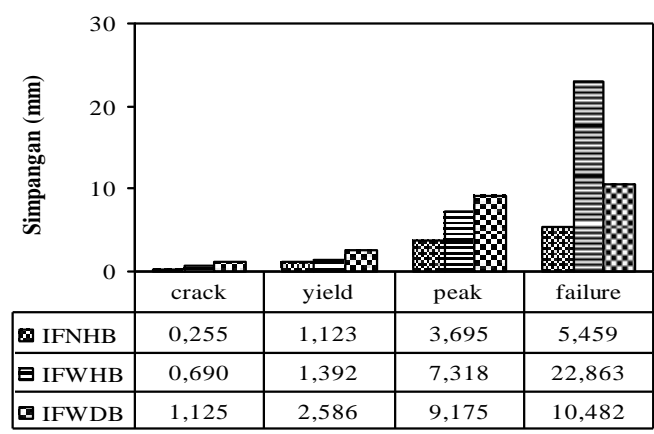

a. initial condition

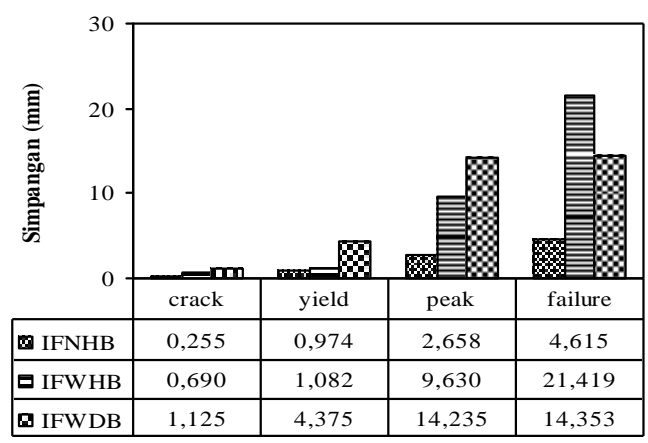

b. stabilized condition

Gambar 9 Simpangan rata-rata pada

Kenaikan simpangan benda uji IFWDB dari benda uji IFNHB pada setiap parameter pengamatan menunjukkan bahwa dengan adanya penambahan tulangan 
diagonal/bracing eksternal pada struktur dinding menambah kemampuan untuk berdeformasi. Nilai simpangan benda uji IFWDB yang lebih rendah dari IFWHB disebabkan karena pola pembebanan IFWDB berdasarkan data simpangan runtuh $\left(\Delta_{u}\right)$ benda uji IFNHB yang nilainya lebih kecil dari pada simpangan runtuh $\left(\Delta_{u}\right)$ benda uji IFWHB pada pengujian statik.

FEMA 306 memberikan pendekatan bahwa deformasi retakan pertama/first crack terjadi pada interstory drift 0,25-0,5\% dan batasan untuk besarnya drift ratio pada infilled frame brick masonry $1,5 \%$. Untuk benda uji IFWDB diperoleh besarnya drift ratio saat first crack pada initial dan stabilized condition sebesar $0,038 \%$ dan saat failure sebesar $0,349 \%$ pada initial condition dan sebesar $0,478 \%$ pada stabilized condition. Nilai ini menunjukkan nilai yang lebih kecil dari pendekatan pada FEMA 306, ini berarti bahwa material yang digunakan dalam struktur IFWDB tidak mampu mempertahankan bentuk/posisinya pada simpangan yang terjadi. Kerusakan telah terjadi pada saat struktur mengalami simpangan yang relatif kecil baik pada retakan pertama maupun kondisi failure.

\section{Kekakuan Struktur}

Besarnya kekakuan struktur tiap siklus dapat dinyatakan dalam persentase terhadap kekakuan awal struktur pada masing-masing benda uji disajikan pada Gambar 10 sampai Gambar 12.

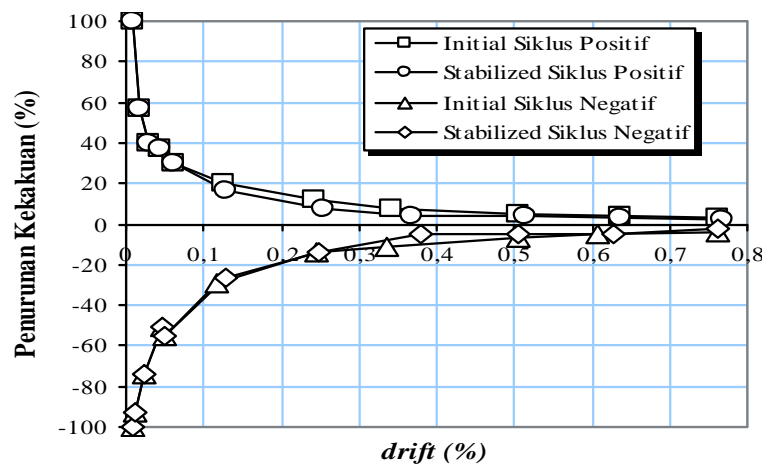

Gambar 10 Persentase penurunan kekakuan benda uji IFWDB

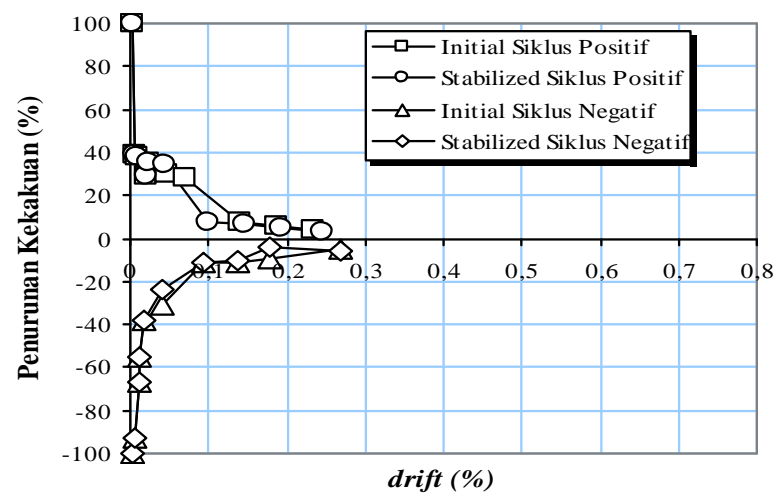

Gambar 11 Persentase penurunan kekakuan benda uji IFNHB

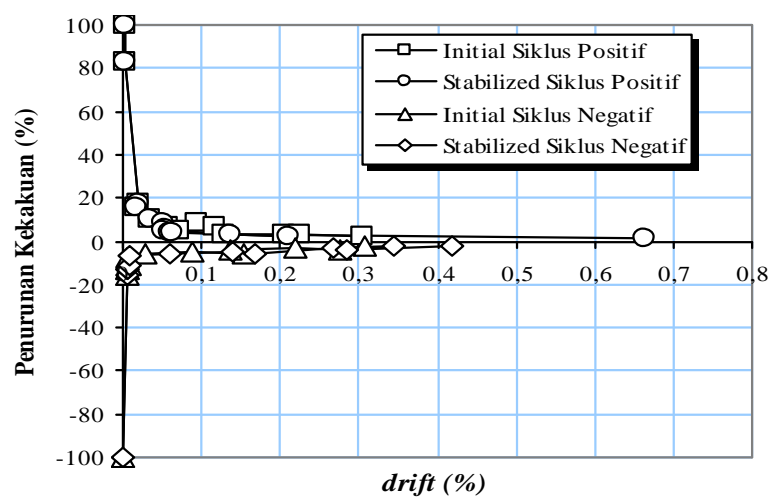

Gambar 12 Persentase penurunan kekakuan benda uji IFWHB

Kekakuan pada benda uji mengalami penurunan secara terus menerus seiring dengan bertambahnya simpangan/drift pada penambahan pembebanan hingga sampai pada siklus terakhir atau benda uji runtuh. Hubungan penurunan kekakuan-drift pada masing-masing benda uji menunjukkan bahwa benda uji IFWDB mengalami penurunan kekakuan dengan simpangan/drift ratio yang hampir sama dengan benda uji IFWHB tetapi dalam kemampuan menahan gaya lateral dan berdeformasi struktur IFWDB lebih baik daripada benda uji IFWHB. Ini menunjukkan bahwa penambahan tulangan diagonal/bracing eksternal membuat struktur dinding juga mampu mempertahankan kekakuannya. 


\section{E. Energi Hysteretic Struktur}

Besarnya energi hysteretic dihitung berdasarkan pendekatan numerik dengan cara menghitung luasan tiap pias pada siklus positif maupun negatif untuk initial dan stabilized condition. Hasil pengujian pada initial dan stabilized condition secara grafis ditampilkan pada Gambar 13.

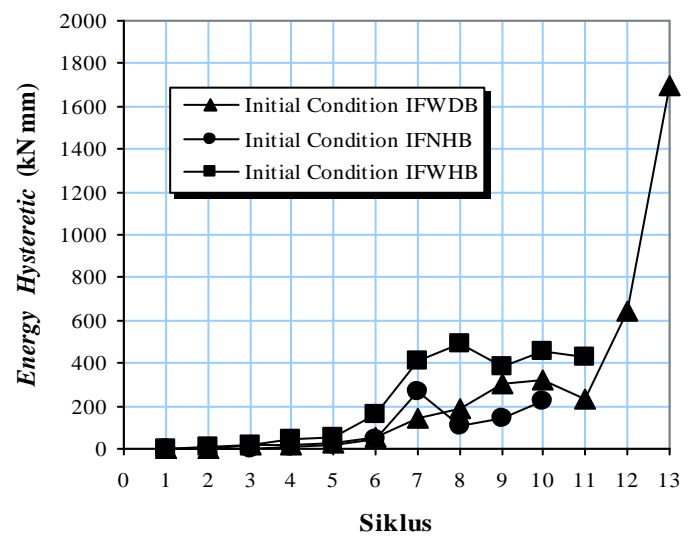

a initial condition

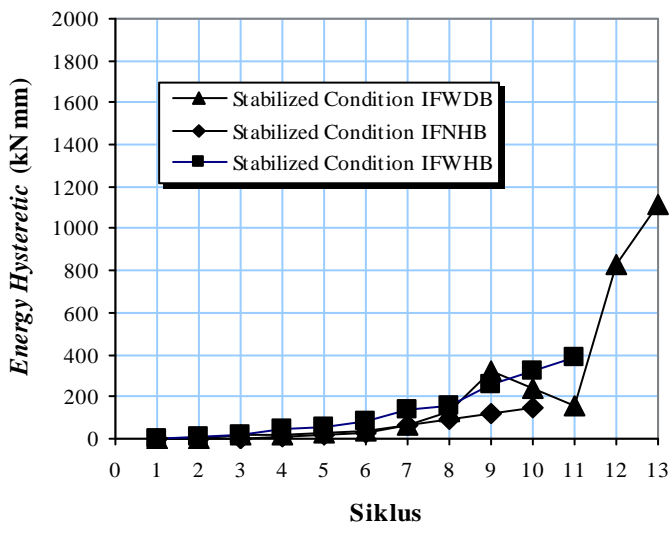

b stabilized condition

Gambar 13 Grafik energi hysteretic

Penambahan tulangan pada pasangan dinding bata merah mempengaruhi energi hysteretic yang dimiliki oleh struktur. Gambar 13 menunjukkan benda uji IFWHB memiliki energy hysteretic yang sedikit lebih besar dari benda uji IFWDB dikarenakan karena pola pembebanan IFWDB berdasarkan data simpangan runtuh $\left(\Delta_{u}\right)$ benda uji IFNHB yang nilainya lebih kecil dari pada simpangan runtuh $\left(\Delta_{u}\right)$ benda uji IFWHB pada pengujian statik. Penambahan tulangan horisontal atau diagonal eksternal menyebabkan struktur dinding lebih mampu untuk menyerap energi daripada tanpa penambahan tulangan.

\section{F. Energi Potensial}

Energi potensial digambarkan sebagai kemampuan untuk melakukan gerakan atau gaya dari dalam (internal force) dari struktur tersebut pada setiap siklus baik pada initial maupun stabilized condition. Secara grafis besarnya energi potensial yang ada pada masing-masing benda uji dapat dilihat pada Gambar 14.

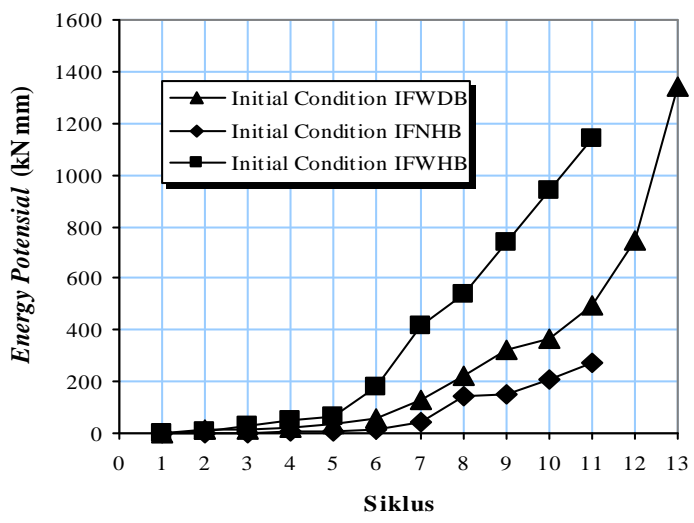

a initial condition

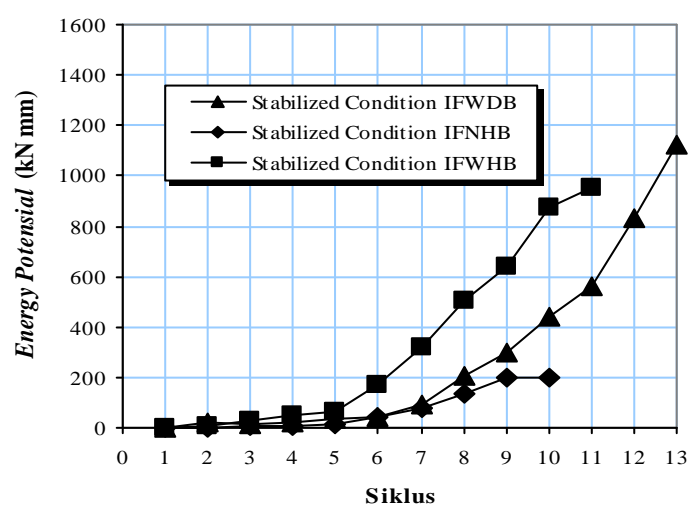

b stabilized condition

Gambar 14 Energi potensial tiap siklus

Gambar di atas menunjukkan benda uji IFWHB memiliki energy potensial yang paling besar diikuti benda uji IFWDB dan benda uji IFNHB. Penambahan tulangan baik horisontal atau diagonal eksternal menyebabkan struktur dinding lebih mampu untuk melakukan gaya dalam daripada tanpa penambahan tulangan. 


\section{G. Equivalent Viscos Damping Ratio (EVDR)}

Penyerapan energi akan berjalan sangat efektif apabila struktur mempunyai ratio redaman cukup besar dan durasi pembebanan yang relatif lama. Redaman yang efektif selanjutnya akan banyak mengurangi atau mengeliminasi goyangan (Widodo, 2001). Secara grafis besarnya nilai EVDR dari benda uji dapat dilihat pada Gambar 15 berikut ini.

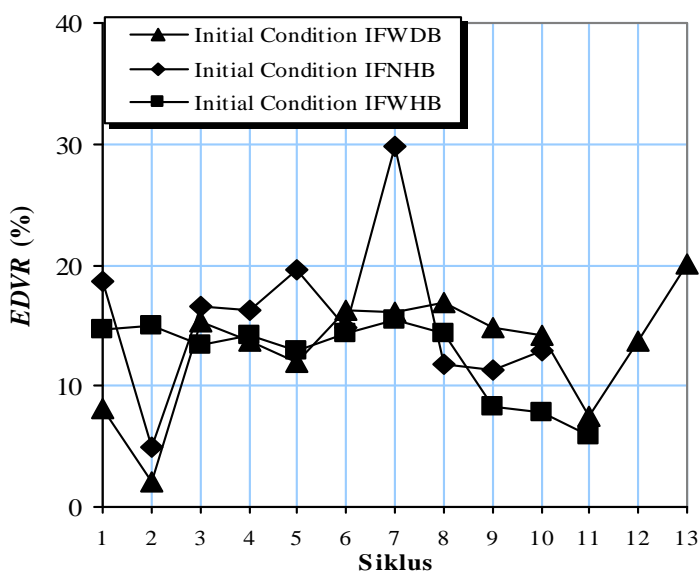

a initial condition

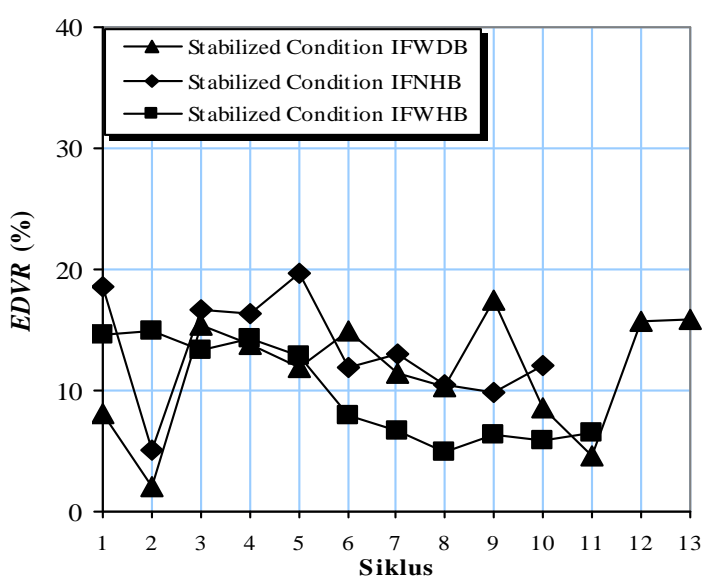

b stabilized condition

Gambar 15 Grafik equivalent viscous damping ratio tiap siklus

Harga dari koofesien redaman adalah jauh lebih kecil dari koofesien redaman kritis dan biasanya diantara 2 sampai dengan 20\% dari harga redaman kritis (Paz, 1987). Dari hasil pengujian tampak bahwa rata-rata nilai
EVDR berada di bawah 20\%, hal ini sesuai dengan yang dikemukakan oleh Paz.

\section{H. Daktilitas Struktur}

Daktilitas struktur secara umum menggambarkan kemampuan struktur untuk berdeformasi di atas batas lelehnya. Secara grafis besarnya nilai daktilitas struktur dapat dilihat pada Gambar 16.

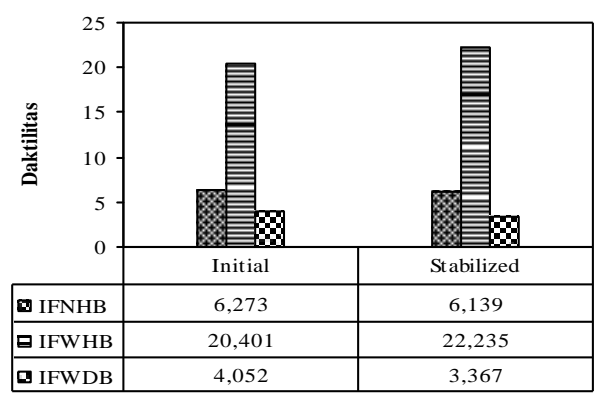

Gambar 16 Nilai daktilitas struktur pada kondisi initial dan stabilized condition

Berdasarkan Gambar 16 terlihat nilai daktilitas benda uji IFNHB sedikit lebih besar, namun pada perencanaan struktur tahan gempa kemampuan menyerap energi gempa untuk benda uji IFWDB lebih bagus dari benda uji IFNHB pada perencanaan beban gempa yang sama dapat dilihat pada Gambar 3.

\section{Kekakuan Elastik Equivalent $\left(k_{e}\right)$}

Kekakuan elastik equivalent dihitung berdasarkan besarnya beban pada saat mencapai 0,4 $P_{\text {peak }}$. Hasil pengujian secara grafis ditunjukkan dalam Gambar 17.

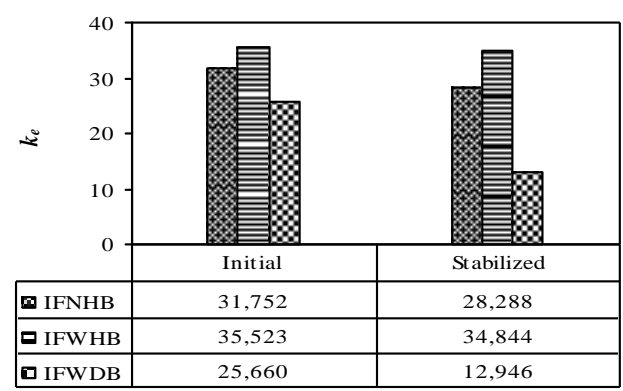

Gambar 17 Kekakuan elastik equivalent saat $0,4 P_{\text {peak }}$ pada initial dan stabilized condition

Gambar di atas menunjukkan kekakuan elastik equivalent dari benda uji IFWDB 
pada initial condition dan stabilized condition lebih rendah terhadap IFNHB dan IFWHB.

\section{J. Maximum Shear Strength}

Maximum shear strength merupakan besarnya beban lateral maksimum yang dapat ditahan oleh struktur sepanjang bentang struktur tersebut. Besarnya gaya geser maksimum/maximum shear strength benda uji IFWDB ditunjukkan pada Gambar 18.

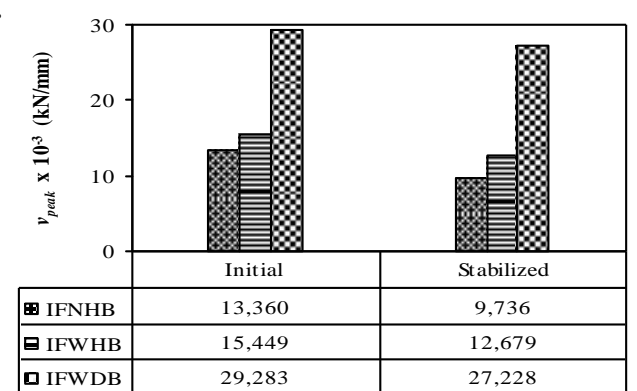

Gambar 18 Nilai maximum shear strength

Gambar di atas menunjukkan nilai maximum shear strength pada benda uji IFWDB mengalami peningkatan sebesar 119,184\% pada initial condition dan 179,663 \% pada stabilized condition terhadap benda uji IFNHB, ini menunjukkan bahwa dengan adanya penambahan tulangan diagonal eksternal dapat meningkatkan tahanan geser maksimum.

\section{K. Pola Kerusakan Struktur}

Pola kerusakan struktur pada benda uji IFWHB merupakan gabungan antara shear failure dan sliding failure, sedangkan pada IFWDB secara keseluruhan didominasi oleh shear failure. Tipe kerusakan IFWDB dapat dilihat pada Gambar 19.

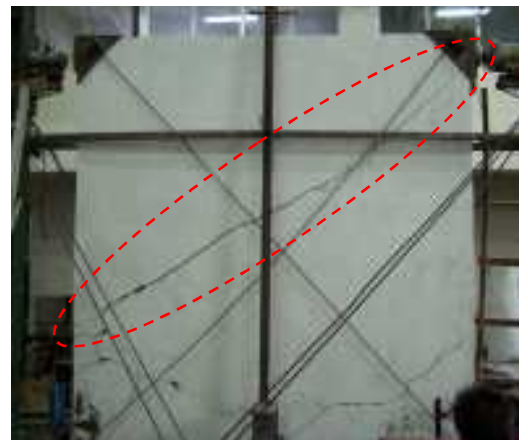

Gambar 19 Pola retak benda uji IFWHB

\section{KESIMPULAN}

Berdasarkan pengujian yang telah dilakukan maka dapat disimpulkan bahwa dengan penambahan tulangan diagonal/bracing eksternal pada dinding bata merah mempengaruhi kemampuan struktur sebagai berikut :

1. Meningkatkan kemampuan struktur dalam menerima beban pada parameter pengamatan saat crack, yield, ultimate, dan failure terhadap benda uji IFNHB. Saat initial condition berturut-turut sesuai dengan parameter pengamatan mengalami peningkatan sebesar 72,195\%; 93,782\%; 119,190\%; 119,190\%, dan pada stabilized condition sebesar 72,195\%; 110,667\%; 179,650\%; 174,713\%.

2. Meningkatkan simpangan struktur pada parameter pengamatan saat crack, yield, ultimate, dan failure terhadap benda uji IFNHB. Saat initial condition berturut- turut sesuai dengan parameter pengamatan mengalami peningkatan sebesar 344,176\%; 130,276\%; 148,309\%; 92,013\%, dan pada stabilized condition sebesar 344,176\%; 349,179\%; 435,553\%; $211,008 \%$.

3. Meningkatkan maximum shear strength sebesar $119,184 \%$ pada initial condition dan $179,663 \%$ pada stabilized condition terhadap benda uji IFNHB.

4. Meningkatkan besarnya energi hysteretic dan energi potensial struktur pada setiap siklus pada initial maupun stabilized condition.

\section{DAFTAR ACUAN}

ASTM, 2003, Standard Test Methods for Cyclic (Reversed) Load Test for Shear Resistance of Walls for Buildings, Designation: Vol 405, E 2126 - 02a.

FEMA 306, 1998, Evaluation of Earthquake Damaged Concrete and Masonry Wall Buildings, Basic Procedures Manual, 555 Twin Dolphin Drive, Suite 550 Redwood City, California.

Goto, T., Mizuno, H., liba, M., Kato, H., 2003, Structural Behavior of Confined Masonry Wall, National Institut for Land and Infrastruktur Management, Japan. 
Mangkoesoebroto, S. P., Goto, T., Tambunan, S., 2003, Experimental and Numerical Study of Confined Masonry Wall Under Cyclic Loading, International workshop, ASLI Building, ITB.

Paz M., 1987, Dinamika Struktur Teori dan Perhitungan, Erlangga, Jakarta.

Raharjo E. P., 2005, Karakteristik Pasca Elastik Dinding Bata Merah dengan Tulangan Horizontal Akibat Beban Bolak-Balik, Tesis, Program Studi Teknik Struktur, Pascasarjana, Universitas Gadjah Mada, Yogyakarta.

Setyawati, 2005, Karakteristik Pasca Elastik Dinding Bata Merah Pejal dengan Tulangan Horizontal Akibat Beban Statik, Tesis, Program Studi Teknik
Struktur, Pascasarjana, Universitas Gadjah Mada, Yogyakarta

Siddiq, S., 2000, Penelitian Eksperimental Struktur Bangunan Skala Penuh dan Aplikasinya pada Bangunan Rumah Rakyat Tahan Gempa, Lokakarya Nasional Bangunan Rumah Tinggal Sederhana Tahan Gempa, Evaluasi, Rekomendasi, dan Sosialisasi, Yogyakarta.

Tular, R. B., 1981, Perencanaan Bangunan Tahan Gempa, Yayasan Lembaga Penyelidikan Masalah Bangunan, Jl. Tamansari No.84, Bandung.

Widodo, 2001, Respons Dinamik Struktur Elastik, UII Press, Yogyakarta. 